\title{
Effects of Heat and Dissolved Calcium on the Sorption of Uranium(VI) in Bentonite Barrier Systems
}

\author{
DIEM QUYNH QUYNH LA ${ }^{1}$, ALBA GUTIERREZ DIAZ ${ }^{1}$, \\ MARCO VOLTOLINI ${ }^{2}$, SERGIO CARRERO ${ }^{2,3}$, KIRSTEN \\ SAUER $^{4}$, PATRICIA M FOX ${ }^{2}$, AMRITA \\ BHATTACHARYYA ${ }^{1,2}$, FLORIE CAPORUSCIO ${ }^{4}$ AND \\ RUTH TINNACHER ${ }^{1}$
}

${ }^{1}$ California State University East Bay

${ }^{2}$ Lawrence Berkeley National Laboratory

${ }^{3}$ Spanish Council of Scientific Research

${ }^{4}$ Los Alamos National Laboratory

Presenting Author: ruth.tinnacher@csueastbay.edu

Most future nuclear waste repositories will include engineered bentonite barriers to minimize the release of uranium (U) and other radioactive contaminants into the natural environment. Bentonite predominantly consists of montmorillonite clay, but also contains fractions of mineral impurities (e.g., plagioclase, quartz, or calcite). Impacts of decay heat on bentonite have previously been investigated in the 18-year Full-Scale Engineered Barrier Experiment (FEBEX). A past study has focused on the effects of heat on U(VI) sorption to bulk FEBEX bentonite samples and their clay fractions (Fox et al., Applied Geochemistry, 2019). However, data regarding heat-induced changes in U(VI) sorption onto FEBEX impurities have been missing.

In this study, we characterized U(VI) sorption onto FEBEX impurities for heated $\left(95^{\circ} \mathrm{C}\right)$ and cold $\left(20^{\circ} \mathrm{C}\right)$ regions, and in comparison to a control (original FEBEX bentonite). Lab-scale batch sorption experiments were conducted at room-temperature, alkaline $\mathrm{pH}$ and in the absence and presence of $2 \mathrm{mM} \mathrm{CaCl}_{2}$. FEBEX bentonite samples went through dry-sieving, wet-sieving and a series of pyrophosphate extraction steps to separate mineral impurities from clay. Nonetheless, X-ray diffraction data show that montmorillonite concentrations remain fairly high, with $47.8-65.9 \%$ clay in various FEBEX impurity samples. Results from SEM analysis suggest that clay is present as part of mineral aggregates or "trapped" in larger impurity particles, which possibly hinders a clean separation.

In comparison to FEBEX bulk and clay fractions, U(VI) sorption onto impurity fractions was characterized by a lower dependence of U(VI) sorption affinities on solution $\mathrm{pH}$. Furthermore, bulk FEBEX bentonite and its clay fraction show a consistent, slight decrease in U(VI) sorption after heattreatments, across a pH range from $\sim 6.8$ to 7.8 and in the absence/presence of $\mathrm{CaCl}_{2}$. In contrast, no apparent changes in $\mathrm{U}(\mathrm{VI})$ sorption were observed for impurity fractions in the absence/presence of $\mathrm{CaCl}_{2}$ in the lower range of $\mathrm{pH}$ conditions tested. However, heat-treatments did cause a significant decrease in $\mathrm{U}(\mathrm{VI})$ sorption in the presence of $\mathrm{CaCl}_{2}$ above $\mathrm{pH}$ 7.5. We are now working on improving our understanding of the underlying processes driving these trends based on additional sample characterization.

This research is funded through DOE's Nuclear Engineering 